\title{
CHEMICAL FORMS OF HEAVY METALS IN BOTTOM SEDIMENTS OF THE MITRĘGA RESERVOIR
}

\author{
Lidia DĄBROWSKA ${ }^{1}$ \\ Czestochowa University of Technology, Częstochowa, Poland
}

\begin{abstract}
Bottom sediments originating from the Mitręga water reservoir were studied. It was assayed, in what chemical forms heavy metals (zinc, copper, nickel, cadmium and lead) occur in sediments, using the method of sequential extraction BCR. According to the geochemical criteria with respect to the content of $\mathrm{Zn}, \mathrm{Cu}$ and $\mathrm{Ni}$, the sediments in all measuring points were classified as uncontaminated, however because of the $\mathrm{Cd}$ content - as moderately contaminated. The highest $\mathrm{Cu}$ and $\mathrm{Ni}$ content was found in the sediment collected in the southern part of the reservoir, 15 and $11 \mathrm{mg} / \mathrm{kg} \mathrm{d} . \mathrm{m}$, respectively. In the case of $\mathrm{Zn}, \mathrm{Pb}$ and $\mathrm{Cd}$, the sediment collected at the outflow of the Mitrega river was the most contaminated; metal content amounted to $136 ; 35 ; 3 \mathrm{mg} / \mathrm{kg}$ d.m., respectively. Based on the conducted fractionation of heavy metals, it was found that the potential mobility of metals, hence the possibility of secondary pollution of the reservoir open water, are arranged in the following order: $\mathrm{Zn}>\mathrm{Cd}>\mathrm{Ni}>\mathrm{Cu} \sim \mathrm{Pb}$.
\end{abstract}

Keywords: bottom sediments, heavy metals, sequential extraction, mobility.

\section{INTRODUCTION}

Most of heavy metals released into water are bound and transported with suspended matter, the deposition of which leads to the formation of the bottom sediments in water reservoirs. The contaminated sediments can be detrimental to the biological resources of surface water and indirectly to human health. Due to the monitoring requirements, the quality evaluation of bottom sediment, in

\footnotetext{
${ }^{1}$ Corresponding author: Czestochowa University of Technology, Department of Chemistry, Water and Wastewater Technology, Dąbrowskiego st 69, 42-200 Częstochowa, Poland, e-mail: dabrowska@is.pcz.czest.pl, tel. +48343250496
} 
the aspect of its contamination with potentially harmful trace elements, is performed based on geochemical criteria. Dependent on the trace metal concentrations present in the sediment, based on the geochemical background, bottom sediment can be classified, into four different classes [1, 11]: uncontaminated (class I), moderately contaminated (class II), contaminated (class III) and very contaminated (class IV). Probable effect level (PEL) and threshold effect level (TEL) values are used for ecotoxicological evaluation [9]. As a result of a variety of chemical and biochemical processes occurring in watercourses, heavy metals bound in sediments may be released into the water, causing their secondary pollution. Metals bound by adsorption, in particular physical, easily pass into the water. Also metals bound to carbonates can be released when significant acidification of the environment occurs. Cells of some microorganisms can contain heavy metals. After microorganism's death, biomass sediments to the bottom and is biochemically degraded. Bioaccumulated heavy metals, present in cells of microorganisms, can move into the water or can be transformed to the insoluble forms. Significant amount of metal can be trapped in crystalline structure of silicates or can form chemical compounds with insignificant solubility in water. Such metals are practically not available for living organisms and are not considered to be dangerous.

To evaluate the potential threat for an ecosystem by heavy metals deposited in sediments, instead of their total content it is important to identify the chemical forms of metals and their quantitative determination. For this purpose, speciation analysis of heavy metals based on the sequential extraction is used [4, 18]. It divides metals' fractions into the following groups: i) exchangeable, ii) associated with carbonates, iii) with hydrated iron and manganese oxides, i) with organic matter and sulfides, v) metals that can be found in the residual fraction. Metals that can be found in the two first fractions (exchangeable and carbonate) are believed to be potentially mobile. Metals found in the fraction of iron and manganese oxides are sensitive to redox changes.

Speciation analysis of heavy metals was applied i.e. for research of bottom sediments of reservoirs Rybnicki [8], Krempna and Zesławice [10], Kozłowa Góra [16], in Poraj [15], lakes in Wielkopolski National Park [17], Taihu Lake [21], Doirani and Kerkini Lakes [13], Dongting Lake [19].

The aim of this study was to estimate the contamination level of bottom sediments of the Mitrega Reservoir with heavy metals $(\mathrm{Zn}, \mathrm{Cu}, \mathrm{Ni}, \mathrm{Cd}, \mathrm{Pb})$ and their distribution in the chemical fractions, separated using a sequential extraction. Potential mobility of metals and the possibility of secondary water pollution were evaluated. The obtained results can serve as a reference level for monitoring research in the future, regarding the recreational function of the reservoir (municipal swimming pool, angling competitions). 


\section{METHODOLOGY}

The Mitręga reservoir is located in the Mitręga river valley, in the town Łazy, Silesia voivodeship (Poland). The area of the reservoir covers 7.7 ha, depth up to $2.5 \mathrm{~m}$. The reservoir is used mainly for fishing, in the summer as a guarded swimming pool. As a small water reservoir, it is not included in a program of monitoring studies.

Bottom sediment samples were collected from the surface layer of the sediment, to a depth of $5 \mathrm{~cm}$, in June 2013 at 4 sites (Fig. 1). Sampling points were located in a way to show the distribution of contaminants in different locations of the Mitrega reservoir. The first sampling point was located on the western side of the reservoir, near the outflow of the Mitrega river, the second on the southern shore. The third sampling point was located on the eastern side of the reservoir, near the tributary of the Mitrega river, and the fourth in the northern part, near the beach. The sediments were collected at a distance of 1.5-3 $\mathrm{m}$ from the shore. The level of water to the surface of the sediment layer was about 0.5$0.6 \mathrm{~m}$.

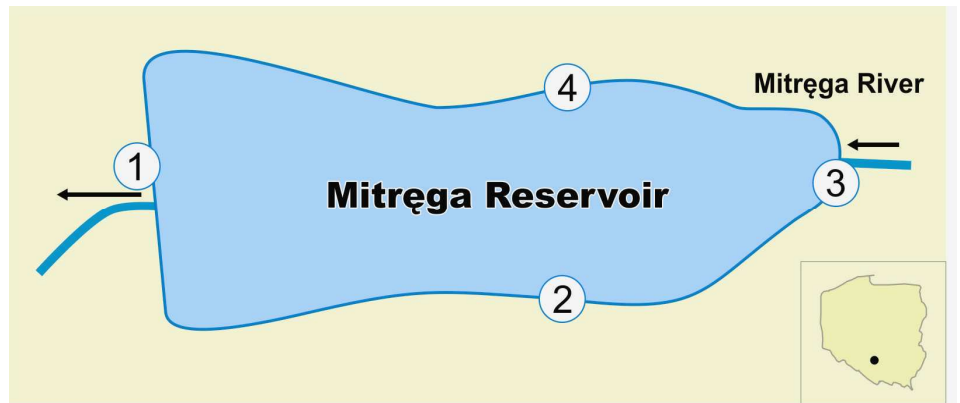

Fig. 1. Location of the Mitrega Reservoir with the sampling points (Poland)

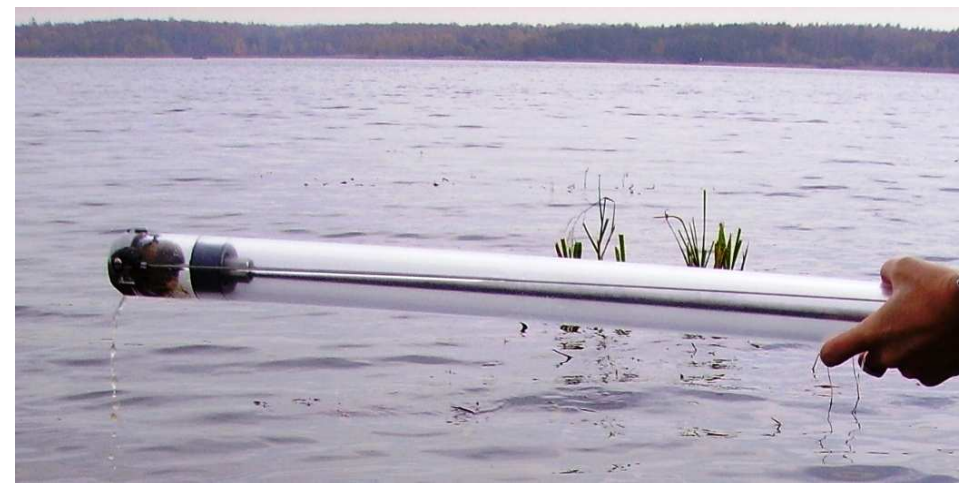

Fig. 2. Tube sampler for bottom sediments sampling 
A glass tubular sampler was used for sediments collection (Fig. 2). The sampler diameter was $4.5 \mathrm{~cm}$. Three samples of sediment were taken out at each site, mixed and stored in plastic containers. Thus four samples were obtained, each sample was an average of three independent sampling of sediments.

The samples of bottom sediments, immediately after arrival in the laboratory, were first dried in air-dry conditions (temp. $22^{\circ} \mathrm{C}$ ) for $48 \mathrm{~h}$, and then in a dryer at $105^{\circ} \mathrm{C}$ for $8 \mathrm{~h}$. Sediment samples were passed through a sieve with $0.2 \mathrm{~mm}$ diameter meshes. In order to monitor bottom sediments in Poland, the concentration of heavy metals is determined in the fraction of particle size $<0.2$ $\mathrm{mm}$ [2]. For separated fraction of sediment with the grains diameter lower than $0.2 \mathrm{~mm}$, which was about $60-65 \%$ of total analyzed material, the total content of heavy metals was determined.

Three different samples of the same sediment were prepared for the analyses. In order to determine the total content of heavy metals, $1.5( \pm 0.001) \mathrm{g}$ of dry sediment was placed into $15 \mathrm{~mL}$ glass test tubes. Next, $2 \mathrm{~mL}$ of $65 \% \mathrm{HNO}_{3}$ and $6 \mathrm{~mL}$ of $37 \% \mathrm{HCl}$ (aqua regia) were added [3]. The sediment underwent mineralization at $120^{\circ} \mathrm{C}$ for $2 \mathrm{~h}$. The samples were stored at $4^{\circ} \mathrm{C}$ for further analyses of heavy metals: zinc, copper, nickel, cadmium, and lead with the use of atomic absorption spectrometry method (spectrometer novAA 400, Analytik Jena).

For bottom sediments, speciation analysis of heavy metals was also done according to BCR scheme presented in Table 1. Detailed specification of performed procedure was described elsewhere [14]. Concentration of heavy metals in extracts was determined by atomic absorption spectrometry.

Table 1. BCR sequential extraction procedure [14]

\begin{tabular}{|c|c|c|}
\hline Step & $\begin{array}{l}\text { Extraction conditions per } 1 \mathrm{~g} \text { of dry } \\
\text { matter of sediment }\end{array}$ & Fraction / Forms of metals \\
\hline 1 & $\begin{array}{l}40 \mathrm{~mL} 0.11 \mathrm{M} \mathrm{CH}_{3} \mathrm{COOH} \\
22^{\circ} \mathrm{C}, 16 \mathrm{~h}\end{array}$ & $\begin{array}{l}\text { F1- exchangeable, bound to } \\
\text { carbonates }\end{array}$ \\
\hline 2 & $\begin{array}{l}40 \mathrm{~mL} 0.5 \mathrm{M} \mathrm{NH}_{2} \mathrm{OH} \cdot \mathrm{HCl}(\mathrm{pH}=2), \\
22^{\circ} \mathrm{C}, 16 \mathrm{~h}\end{array}$ & $\begin{array}{l}\mathrm{F} 2 \text { (reducible) - bound to } \mathrm{Fe} \text { and } \\
\text { Mn oxides }\end{array}$ \\
\hline 3 & $\begin{array}{l}10 \mathrm{~mL} 8.8 \mathrm{M} \mathrm{H}_{2} \mathrm{O}_{2}(\mathrm{pH}=2-3), \\
22^{\circ} \mathrm{C}, 16 \mathrm{~h} ; 85^{\circ} \mathrm{C}, 1 \mathrm{~h} \\
10 \mathrm{~mL} 8.8 \mathrm{M} \mathrm{H}_{2} \mathrm{O}_{2}, 85^{\circ} \mathrm{C}, 1 \mathrm{~h} \\
50 \mathrm{~mL} 1 \mathrm{M} \mathrm{CH}_{3} \mathrm{COONH}_{4}, 22^{\circ} \mathrm{C}, 16 \mathrm{~h}\end{array}$ & $\begin{array}{l}\text { F3 (oxidizable) - bound to organic } \\
\text { matter and sulfides }\end{array}$ \\
\hline 4 & $\begin{array}{l}2 \mathrm{~mL} 65 \% \mathrm{HNO}_{3}, 6 \mathrm{~mL} 36 \% \mathrm{HCl}, \\
120^{\circ} \mathrm{C}, 2 \mathrm{~h}\end{array}$ & F4 - residual \\
\hline
\end{tabular}

The overall concentration of metals in the sediment (Total) determined after mineralization with aqua regia was compared with the sum of metal 
concentrations in the extracted fractions $(\mathrm{F} 1+\mathrm{F} 2+\mathrm{F} 3+\mathrm{F} 4)$. Recovery in the sequential extraction procedure was calculated as follows [5]:

$$
\text { Recovery } \%=\frac{\mathrm{F} 1+\mathrm{F} 2+\mathrm{F} 3+\mathrm{F} 4}{\text { Total }} \cdot 100
$$

\section{RESULTS AND DISCUSSION}

Total heavy metals content in bottom sediments sampled in respective sites (sampling points), and geochemical criteria of bottom sediments classification, are presented in Table 2 .

Table 2 . The total content of heavy metals in bottom sediments (mean, $\mathrm{n}=3$ )

\begin{tabular}{|c|c|c|c|c|c|}
\hline \multirow{2}{*}{ Sediment } & \multicolumn{5}{|c|}{ Content, mg/kg d.m. } \\
\cline { 2 - 6 } & $\mathrm{Zn}$ & $\mathrm{Cu}$ & $\mathrm{Ni}$ & $\mathrm{Cd}$ & $\mathrm{Pb}$ \\
\hline From point 1 & $136 \pm 5$ & $11.3 \pm 0.5$ & $7.9 \pm 0.4$ & $2.7 \pm 0.3$ & $35.0 \pm 1.4$ \\
\hline From point 2 & $98 \pm 4$ & $15.2 \pm 0.7$ & $11.4 \pm 0.5$ & $1.9 \pm 0.2$ & $28.5 \pm 1.1$ \\
\hline From point 3 & $75 \pm 3$ & $8.7 \pm 0.3$ & $4.8 \pm 0.4$ & $1.1 \pm 0.2$ & $15.5 \pm 0.7$ \\
\hline From point 4 & $63 \pm 3$ & $7.8 \pm 0.4$ & $5.6 \pm 0.2$ & $1.6 \pm 0.1$ & $9.0 \pm 0.5$ \\
\hline Uncontaminated [1] & 200 & 40 & 16 & 1.0 & 30 \\
\hline Moderately & 500 & 100 & 40 & 3.5 & 100 \\
\hline contaminated [1] & 123 & 36 & 18 & 0.6 & 35 \\
\hline Value TEL [9] & 315 & 197 & 36 & 3.5 & 91 \\
\hline Value PEL [9] & & & & & \\
\hline
\end{tabular}

Bottom sediments sampled from the Mitrega reservoir were characterized by varied heavy metal contents. The highest content of copper $15 \mathrm{mg} / \mathrm{kg} \mathrm{d.m}$. and nickel $11 \mathrm{mg} / \mathrm{kg}$ d.m. was found in the sediment sampled from point 2 (in the southern part of the reservoir). In the case of zinc, lead, and cadmium, the most contaminated was sediment taken from site 1 , at the outflow of the Mitrega river; the content of metals amounted to $136 ; 35 ; 2.7 \mathrm{mg} / \mathrm{kg}$ d.m., respectively. The lowest levels of nickel and cadmium, respectively, 4.8 and $1.1 \mathrm{mg} / \mathrm{kg} \mathrm{d.m}$., were found in the sediment collected in the eastern part of the reservoir, at the tributary of the Mitrega river, while zinc, copper and lead, respectively 63; 7.8 and $9 \mathrm{mg} / \mathrm{kg} \mathrm{d.m.,} \mathrm{in} \mathrm{the} \mathrm{sediment} \mathrm{collected} \mathrm{near} \mathrm{the} \mathrm{beach,} \mathrm{in} \mathrm{the} \mathrm{northern} \mathrm{part}$ of the reservoir. A significant difference of metal content in the sediments at the tributary and at the outflow of the river to the reservoir indicates that in the 
western part, the reservoir retains these metals along with the sedimenting suspended matter.

The classification of bottom sediments from the Mitrega reservoir was performed based on contamination assessment criteria for water sediments, and PEL and TEL values. Based on the results (Table 2), it can be stated that according to geochemical criteria considering content of zinc, copper, and nickel, sediments in all research sites were classified as uncontaminated, whereas considering cadmium content - as moderately contaminated. Because of lead content, sediment sampled in the eastern part of the reservoir (outflow of the river) was classified as moderately contaminated. Contamination of the sediments did not differ significantly from analyzed in Poland lacustrine sediments within the subsystem of the State Environmental Monitoring "Monitoring the quality of inland surface water". Geochemical research of 129 samples of bottom sediments from lakes, carried out in the framework of the monitoring in 2012, showed that because of the content of zinc, copper, lead, nickel and cadmium respectively in $97 ; 75,85,42,83 \%$ of lakes sediments were uncontaminated, whereas $2 ; 24 ; 13,57,16 \%$ moderately contaminated [11].

In bottom sediments derived from all research points in the Mitrega reservoir, content of analyzed metals did not exceed the PEL value. TEL value $(0.6$ $\mathrm{mg} / \mathrm{kg}$ ) was exceeded in the case of cadmium in sediments sampled from sampling points $1,2,3,4$, and it amounted to $2.7 ; 1.9 ; 1.1 ; 1.6 \mathrm{mg} / \mathrm{kg} \mathrm{d}$.m., respectively. Also, for zinc content equal to $136 \mathrm{mg} / \mathrm{kg} \mathrm{d}$.m. in sediment sampled in point 1 (the eastern part of the reservoir, the outflow of the river) the TEL value $(123 \mathrm{mg} / \mathrm{kg})$ was exceeded.

The content of the determined chemical forms of heavy metals in bottom sediments is presented in Table 3 and Figure 3.

The sum of zinc, copper, nickel, lead, and cadmium content in four analyzed fractions was $88-111 \%$ of total concentration in sediments determined without fractionation, confirming the correctness of the used methodology and reliability of the obtained results $[6,20]$.

Table 3. Content of chemical forms of heavy metals in bottom sediments (mean, $n=3$ )

\begin{tabular}{|c|c|c|c|c|c|c|}
\hline & \multirow{2}{*}{$\begin{array}{l}\text { Chemical } \\
\text { fraction }\end{array}$} & \multicolumn{5}{|c|}{ Content, mg/kg d.m. } \\
\hline & & $\mathrm{Zn}$ & $\mathrm{Cu}$ & $\mathrm{Ni}$ & $\mathrm{Cd}$ & $\mathrm{Pb}$ \\
\hline \multirow{5}{*}{ 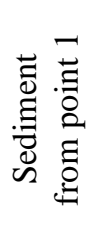 } & $\mathrm{I}$ & $43 \pm 3$ & $0.6 \pm 0.1$ & $1.1 \pm 0.1$ & $0.5 \pm 0.1$ & $2.7 \pm 0.2$ \\
\hline & II & $34 \pm 3$ & $1.0 \pm 0.2$ & $1.2 \pm 0.2$ & $0.8 \pm 0.2$ & $18.0 \pm 0.6$ \\
\hline & III & $25 \pm 2$ & $5.8 \pm 0.4$ & $2.8 \pm 0.3$ & $0.5 \pm 0.1$ & $13.6 \pm 0.4$ \\
\hline & IV & $45 \pm 2$ & $3.2 \pm 0.3$ & $2.1 \pm 0.3$ & $0.8 \pm 0.1$ & $3.7 \pm 0.3$ \\
\hline & Sum & 147 & 10.6 & 7.2 & 2.6 & 38.0 \\
\hline
\end{tabular}


OF THE MITRĘGA RESERVOIR

\begin{tabular}{|c|c|c|c|c|c|c|}
\hline & $\%$ recovery & 108 & 94 & 91 & 96 & 109 \\
\hline \multirow{6}{*}{ 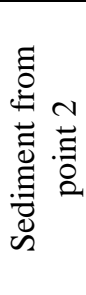 } & I & $28 \pm 2$ & $1.1 \pm 0.2$ & $1.4 \pm 0.2$ & $0.7 \pm 0.1$ & $3.0 \pm 0.2$ \\
\hline & II & $24 \pm 3$ & $1.3 \pm 0.1$ & $1.2 \pm 0.1$ & $0.8 \pm 0.2$ & $10.6 \pm 0.6$ \\
\hline & III & $19 \pm 1$ & $8.3 \pm 0.4$ & $2.9 \pm 0.2$ & $0.4 \pm 0.1$ & $9.8 \pm 0.4$ \\
\hline & IV & $20 \pm 2$ & $5.3 \pm 0.3$ & $6.5 \pm 0.4$ & $0.2 \pm<0.1$ & $3.9 \pm 0.4$ \\
\hline & Sum & 91 & 16.0 & 12.0 & 2.1 & 27.3 \\
\hline & $\%$ recovery & 93 & 105 & 105 & 111 & 96 \\
\hline \multirow{6}{*}{ 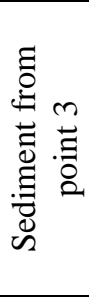 } & I & $25 \pm 2$ & $1.3 \pm 0.2$ & $1.0 \pm 0.2$ & $0.2 \pm<0.1$ & $2.0 \pm 0.2$ \\
\hline & II & $15 \pm 1$ & $1.5 \pm 0.2$ & $2.0 \pm 0.2$ & $0.5 \pm 0.1$ & $7.5 \pm 0.5$ \\
\hline & III & $14 \pm 2$ & $3.7 \pm 0.3$ & $1.1 \pm 0.1$ & $0.2 \pm<0.1$ & $3.6 \pm 0.3$ \\
\hline & IV & $18 \pm 1$ & $1.9 \pm 0.2$ & $1.0 \pm 0.1$ & $0.3 \pm 0.1$ & $1.1 \pm 0.1$ \\
\hline & Sum & 72 & 8.4 & 5.1 & 1.2 & 14.2 \\
\hline & $\%$ recovery & 96 & 97 & 106 & 109 & 92 \\
\hline \multirow{6}{*}{ 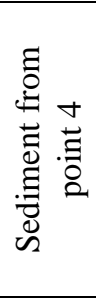 } & I & $19 \pm 2$ & $2.0 \pm 0.3$ & $1.5 \pm 0.2$ & $0.3 \pm 0.1$ & $1.9 \pm 0.2$ \\
\hline & II & $11 \pm 1$ & $1.9 \pm 0.2$ & $0.9 \pm 0.1$ & $0.2 \pm<0.1$ & $3.6 \pm 0.4$ \\
\hline & III & $9 \pm 1$ & $2.3 \pm 0.2$ & $1.0 \pm 0.1$ & $0.2 \pm<0.1$ & $1.7 \pm 0.2$ \\
\hline & IV & $27 \pm 3$ & $1.9 \pm 0.3$ & $1.8 \pm 0.2$ & $0.7 \pm 0.1$ & $2.4 \pm 0.2$ \\
\hline & Sum & 66 & 8.1 & 5.2 & 1.4 & 9.6 \\
\hline & $\%$ recovery & 105 & 104 & 93 & 88 & 107 \\
\hline
\end{tabular}

Fraction: I - exchangeable, carbonates-bound, II - Fe/Mn oxides-bound,

III - organic matter/sulfides-bound, IV - residual (non-dissolved compounds)

Zinc in sediments sampled from research sampling points 2 and 3, occurred in the largest amount in mobile fraction - exchangeable and carbonate (28 and 25 $\mathrm{mg} / \mathrm{kg}$ d.m., respectively $31 \%$ and $35 \%$ ), whereas from research sites 1 and 4 in residue fraction ( 45 and $27 \mathrm{mg} / \mathrm{kg} \mathrm{d.m}$., respectively $31 \%$ and $41 \%$ ), which is in practically insoluble compounds. The lowest amount of zinc was bound to organic sulfide fraction. Lead occurred mostly in fraction associated with hydrated iron and manganese oxides (3.6-18 mg/kg d.m.). Content in this fraction amounted in sediments sampled from points $1,2,3,4$ respectively to $47 ; 39 ; 53 ; 37 \%$ in relation to total content. The largest amount of copper was bound to organic-sulfide fraction, 3.7-8.3 $\mathrm{mg} / \mathrm{kg}$ d.m. (44-55\%). One exception was sediment sampled from point 4 , in which copper occurred in every fraction in comparable amounts. The share of exchangeable and carbonate fraction, which is the most available, in bounding of copper was the smallest (0.6-2 $\mathrm{mg} / \mathrm{kg} \mathrm{d.m}$.). Cadmium as well as nickel content in sediment chemical fractions was differential depending on sampling site. In sediment sampled from point 1 , cadmium occurred mainly in hydrated iron and manganese oxides fraction, and in practically insoluble compounds - residue fraction (both 33\%), in sediment 
from point 2 in hydrated iron and manganese and carbonate exchangeable fractions (38 and 33\%), whereas from point 4 - in practically insoluble compounds (50\%). In bounding nickel, in sediment sampled from points 2 and 4, dominant fraction was residue (respectively $54 \%$ and $35 \%$ with respect to total amount), in sediment from point 3 - hydrated iron and manganese oxides (39\%), whereas in sediment from point 1 - organic sulfide (39\%).

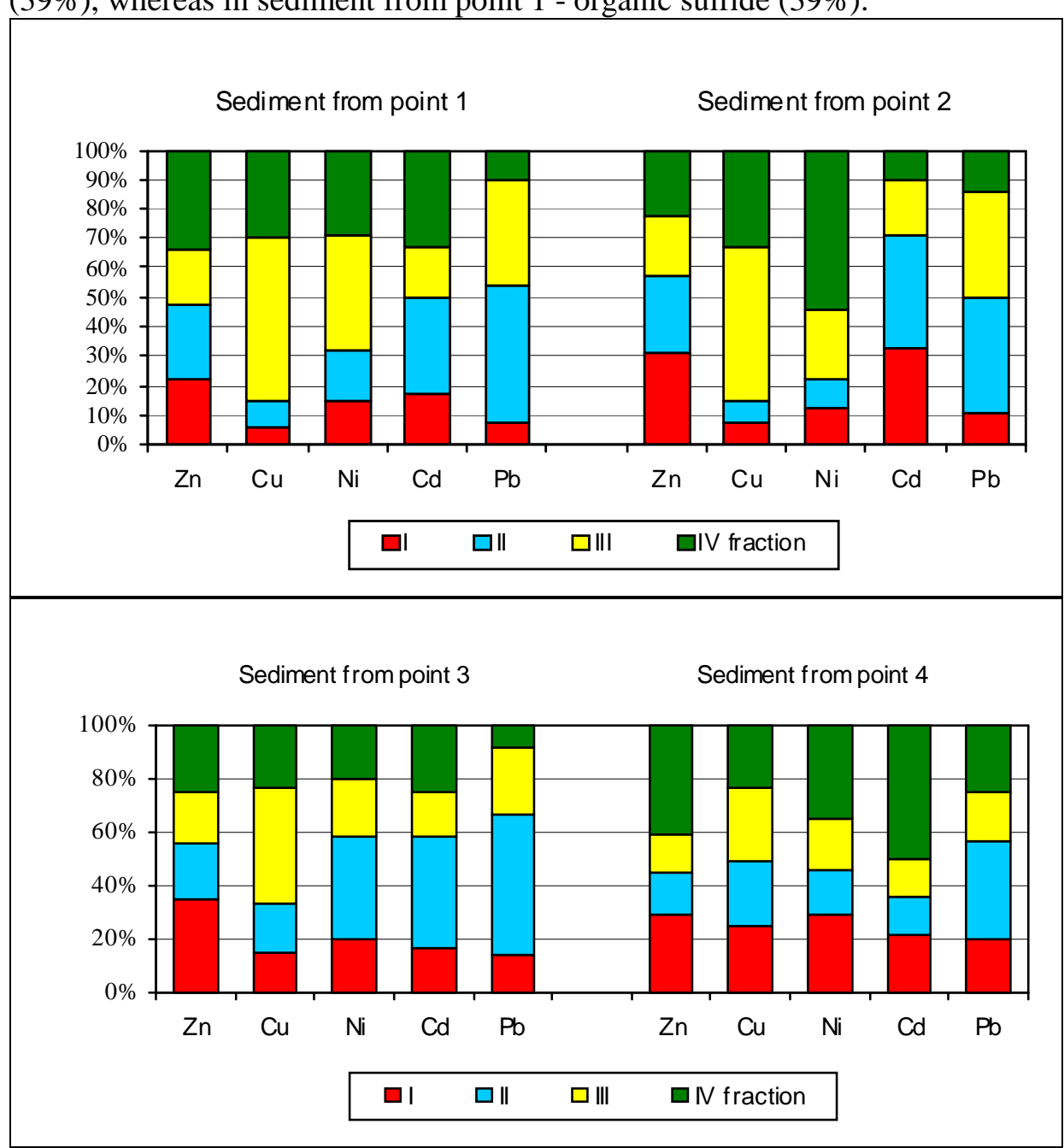

Fig. 3. Percentage distribution of heavy metals in fractions of sediments:

I - exchangeable/carbonates, II - Fe/Mn oxides, III - organic matter/sulfides, IV - residual 
A significant role of residual fraction in binding of nickel was obtained in studies of sediments from Lake Dongting [19] or Lake Nashina [7]. In case of copper, sediment research conducted by Pakuła et al. [12] have confirmed its presence mainly in the organic-sulfide fraction, whereas carried out by $\mathrm{Li}$ et al. [7] and Yao et al. [19] in the residual fraction. The carbonate fraction had a significant share in the total content of cadmium and lead in sediments from the Poraj reservoir [15], lead from the Rybnicki reservoir [8], and cadmium in the sediments studied by Li et al. [7] and Yao et al [19]. Also a significant role of iron and manganese oxides fraction in binding of lead has been demonstrated in research of a variety of bottom sediments from lakes [17, 19] and from the Kozłowa Góra reservoir [16].

Based on conducted heavy metal fractionation, it was stated that their potential mobility, and therefore the possibility of secondary contamination of reservoir aqueous phase, aligns as follow: $\mathrm{Zn}>\mathrm{Cd}>\mathrm{Ni}>\mathrm{Cu} \sim \mathrm{Pb}$. This order was obtained based on percentage share of metals in exchangeable and carbonate fractions, which are considered to be the most mobile. In case of quantitative evaluation, content in $\mathrm{mg} / \mathrm{kg}$, the order was as follow: $\mathrm{Zn}>\mathrm{Pb}>\mathrm{Cu} \sim \mathrm{Ni}>\mathrm{Cd}$. Thus, in the fraction including mobile, exchangeable and carbonate forms, sensitive to changes in the environmental conditions (salinity, $\mathrm{pH}$ ), the highest amount of zinc in total content of this metal in sediments was stated.

Based on heavy metal content in exchangeable and carbonate fractions of sediments, it can also be estimated, which of the sites in the reservoir are the most vulnerable to metal release from sediments to aqueous phase. It was stated that the largest possibility of zinc release was regarding bottom sediments in research point 1 (the eastern part of the reservoir, the outflow of the river), lead, cadmium, and nickel - sediments in point 2 (the southern part of the reservoir), whereas copper - in point 4 (the western part of the reservoir, the tributary of the river). Research, although conducted in a small reservoir, confirms that for the evaluation of potential pollution of open water from heavy metals deposited in bottom sediments, identification of chemical forms of these metals is essential.

\section{CONCLUSIONS}

Based on obtained results, following conclusions were drawn:

- according to geochemical criteria considering zinc, lead, copper and nickel content, sediments in all research sites were classified as uncontaminated, whereas considering cadmium content as moderately contaminated. Potential toxic impact on living organisms can be caused by cadmium, as content of only this metal exceeded TEL value; 
- the largest copper and nickel content occurred in the sediment collected in the southern part of the reservoir, while zinc, lead and cadmium in the sediment collected at the outflow of the Mitregga river. The highest amount in potentially mobile exchangeable-carbonate fraction of the sediments was stated for zinc, which may result in secondary contamination of the water reservoir.

\section{REFERENCES}

1. Bojakowska I.: Kryteria oceny zanieczyszczenia osadów wodnych, Przegląd Geologiczny, 49, 3 (2001) 213-218.

2. Bojakowska I., Gliwicz T., Małecka K.: Wyniki geochemicznych badań osadów wodnych Polski $w$ latach 2003-2005, Inspekcja Ochrony Środowiska, Biblioteka Monitoringu Środowiska, Warszawa 2006.

3. European Committee for Standardization, Characterization of sludges Determination of trace elements and phosphorus - Aqua regia exctracion methods, EN 13346:2000.

4. Glyzes Ch., Tellier S., Astruc M.: Fractionation studies of trace elements in contaminated soils and sediments: a review of sequential extraction procedures, Trends in Analytical Chemistry, 21, (2002) 451-467.

5. Hulanicki A.: Wspótczesna chemia analityczna. Wybrane zagadnienia (Contemporary analytical chemistry. Selected problems), Wydawnictwo Naukowe PWN, Warszawa 2001.

6. Kelderman P., Osman A.A.: Effect of redox potential on heavy metal binding forms in polluted canal sediments in Delft (The Netherlands), Water Research, 41, (2007) 4251-4261.

7. Li M., Zang S., Xiao $\mathrm{H}$. , Wu Ch.: Speciation and distribution characteristics of heavy metals and pollution assessments in the sediments of Nashina Lake, Heilongjiang, China, Ecotoxicology, 23, (2014) 681-688.

8. Loska K., Wiechuła D., Pęciak G.: Wykorzystanie analizy specjacyjnej w badaniu biodostępności metali w osadzie dennym Zbiornika Rybnickiego, Problemy Ekologii, 7, 2 (2003) 69-74.

9. MacDonald D.D., Ingersoll C.G., Berger T.A.: Development and evaluation of consensus-based sediment quality guidelines for freshwater ecosystems, Archives of Environmental Contamination and Toxicology, 39, (2000) 2031.

10. Madeyski M., Tarnawski M., Jasiewicz Cz., Baran A.: Fractionation of chosen heavy metals in bottom sediments of small water reservoirs, Archives of Environmental Protection, 35, 3 (2009) 47-57. 
11. Ocena zanieczyszczenia osadów rzek i jezior w 2012 roku, GIOŚ - baza OSADY, www.gios.gov.pl

12. Pakuła K., Jaremko D., Becher M.: Zn, Cu i Ni we frakcjach wydzielonych metoda BCR w osadach dennych, Proceedings of ECopole, 6, 2 (2012), 641-646.

13. Pertsemli E., Voutsa D.: Distribution of heavy metals in Lakes Doirani and Kerkini, Northern Greece, Journal of Hazardous Materials, 148, (2007) 529-537.

14. Rauret G., Lopez-Sanchez J.F., Sahuquillo A., Barahona E., Lachica M., Ure A.M., Davidson C.M., Gomez A., Luck D., Bacon J., Yli-Halla J., Muntau H., Quevauviller Ph.: Application of a modified BCR sequential extraction (three-step) procedure for the determination of extractable trace metal contents in a sewage sludge amended soil reference material (CRM 483), complemented by a three-year stability study of acetic acid and EDTA extractable metal content, Journal of Environmental Monitoring, 2, (2000) 228-233.

15. Rosińska A., Dąbrowska L.: PCB i metale ciężkie $w$ osadach dennych zbiornika zaporowego $w$ Poraju, Inżynieria i Ochrona Środowiska, 11, 4 (2008) 455-469.

16. Rosińska A., Dąbrowska L.: PCBs and heavy metals in water and bottom sediments of the Kozłowa Góra Dam Reservoir, Archives of Environmental Protection, 37, 4 (2011) 61-73.

17. Sobczyński T., Siepak J.: Badanie kumulacji zwiazków biogenicznych $i$ specjacji metali $w$ osadach dennych jezior Wielkopolskiego Parku Narodowego, Zeszyty Naukowe Wydziału Budownictwa i Inżynierii Środowiska Politechniki Koszalińskiej, Seria: Inżynieria Środowiska, 20, (2001) 265-290.

18. Specjacja chemiczna. Problemy i możliwości, edit. Barałkiewicz D., Bulska E.: Wydawnictwo Malamut, Warszawa 2009.

19. Yao Z.: Comparison between BCR sequential extraction and geoaccumulation method to evaluate metal mobility in sediments of Dongting Lake, Central China, Chinese Journal of Oceanology and Limnology, 26, 1 (2008) 14-22.

20. Yu R., Hu G., Wang L.: Speciation and ecological risk of heavy metals in intertidal sediments of Quanzhou Bay, China, Environmental Monitoring and Assessment, 163, (2010) 241-252.

21. Yuan X., Deng X., Shen Z., Gao Y.: Speciation and potential remobilization of heavy metals in sediments of the Taihu Lake, China, Chinese Journal of Geochemistry, 26, 4 (2007) 384-393. 


\section{CHEMICZNE FORMY METALI CIĘŻKICH W OSADACH DENNYCH ZBIORNIKA WODNEGO MITRĘGA}

\section{Streszczenie}

Obiektem badań były osady denne pochodzące ze zbiornika wodnego Mitręga (województwo śląskie, powiat zawierciański). Oznaczono, w jakich formach chemicznych występują metale ciężkie (cynk, miedź, nikiel, kadm i ołów) w osadach dennych, wykorzystując metodę ekstrakcji sekwencyjnej BCR. Oceniono potencjalną mobilność metali i możliwość wtórnego zanieczyszczenia wody.

Według kryteriów geochemicznych ze względu na zawartość cynku, miedzi oraz niklu osady we wszystkich punktach pomiarowych klasyfikowane były jako niezanieczyszczone, natomiast ze względu na zawartość kadmu jako miernie zanieczyszczone. W przypadku ołowiu osad we wschodniej części zbiornika został sklasyfikowany jako miernie zanieczyszczony, w pozostałych jako niezanieczyszczony. Największą zawartość miedzi i niklu stwierdzono w osadzie pobranym w południowej części zbiornika, odpowiednio 15 i $11 \mathrm{mg} / \mathrm{kg}$ suchej masy. W przypadku cynku, ołowiu i kadmu najbardziej zanieczyszczony był osad pobrany na odpływie rzeki Mitręga; zawartość metali wynosiła odpowiednio 136; 35; $3 \mathrm{mg} / \mathrm{kg}$ s.m. Zawartość kadmu we wszystkich pobranych osadach przekroczyła wartość TEL $(0,6 \mathrm{mg} / \mathrm{kg} \quad$ s.m.). Na podstawie przeprowadzonego frakcjonowania metali ciężkich stwierdzono, że potencjalna mobilność metali, a co za tym idzie możliwość wtórnego zanieczyszczenia toni wodnej zbiornika układa się w następującym szeregu: $\mathrm{Zn}>\mathrm{Cd}>\mathrm{Ni}>\mathrm{Cu} \sim \mathrm{Pb}$.

Słowa kluczowe: osady denne, metale ciężkie, mobilność, ekstrakcja sekwencyjna. 